\title{
ANTARCTIC ICE SHEET SURFACE MASS BALANCE ESTIMATES FROM 2003 TO 2015 USING ICESAT AND CRYOSAT-2 DATA
}

\author{
Huan Xie ${ }^{\text {a, b }}$, Gang Hai ${ }^{\text {a, b }}$, Lei Chen ${ }^{\text {a, b }}$, Shijie Liu ${ }^{\text {a, b }}$, Jun Liu ${ }^{\text {a, b }}$, Xiaohua Tong ${ }^{\text {a, b }}$, Rongxing Li a, b, * \\ ${ }^{a}$ College of Surveying and Geo-Informatics, Tongji University, 1239 Siping Road, Shanghai, China - (huanxie, ganghai, \\ 103495chen, liusjtj, xhtong, rli)@ tongji.edu.cn \\ ${ }^{\mathrm{b}}$ Center for Spatial Information Science and Sustainable Development, Tongji University, 1239 Siping Road, Shanghai, China - \\ junliurs@163.com
}

Commission VIII, WG VIII/6

KEY WORDS: Antarctica, Mass Balance, ICESat, CryoSat-2

\begin{abstract}
:
An assessment of Antarctic ice sheet surface mass balance from 2003 to 2015 has been carried out using a combination of ICESat data from 2003 to 2009 and CryoSat-2 data from 2010 to 2015. Both data sets are of L2 and are currently processed separately using different models. First, a repeat-track processing method that includes terms accounting for the trend and the first order fit of topography is applied to repeat-track measurements of all ICESat Campaigns. It uses the Least Squares fitting of the model to all observations in a box of $500 \mathrm{~m} \times 500 \mathrm{~m}$. The estimated trends in these boxes are then averaged inside a $30 \mathrm{~km} \times 30 \mathrm{~km}$ cell. Similarly, the cells are used to estimate basin and ice sheet level surface elevation change trends. Mass balance calculating is performed at the cell level by multiplying the ice density by the volume change and then extended to the basin and the ice sheet level. Second, in CryoSat-2 data processing we applied a model within a cell of $5 \mathrm{~km}$ x $5 \mathrm{~km}$ considering that CryoSat-2 does not maintain repeated tracks. In this model the elevation trend, and a higher order topography are solved in an iterative way using the least squares technique. The mass change is computed at the cell level in the same way as the ICESat data. GIA correction is applied for both ICESat and CryoSat-2 estimates. Detailed information about the data processing, elevation and mass balance changes, and comparison with other studies will be introduced.
\end{abstract}

\section{INTRODUCTION}

Assessing of mass balance in Antarctica has become an important scientific research theme because melting of the Antarctic Ice Sheet and the resulting discharge contribute significantly to changes in sea level (Bamber et al., 2009; Cazenave et al., 2010; Shepherd et al., 2012; Vaugham et al., 2013). The contribution of polar ice sheet changes to sea level rising reveals an accelerating rate compared with changes in the other two major contributors: continental glaciers and expansion of seawater caused by higher temperatures (Domingues et al., 2008; Chen et al., 2009; Cazenave et al., 2010; Rignot et al., 2011; Zwally et al., 2011). Both its vast ice mass and its increasing rate of change make observations of the AIS a high priority. Furthermore, the potential instability of the ice sheet due to effects related to accelerated ice flow, subsurface lakes, and basal ice-shelf melting may significantly affect the overall rate of change, and the ice sheet needs to be closely monitored and modeled using regional and local observations (Ivins, 2009; Flament et al., 2013; Moholdt et al., 2014; Paolo et al., 2015; Liu et al., 2015).

Analysis of mass balance in the Antarctic Ice Sheet can be performed using satellite technologies, including (1) elevation and volume change from radar altimetry (RA) and laser altimetry (LA) (2) mass change from satellite gravimetry (GR), and (3) the input-output method (IOM) using ice-velocity sensing for mass output estimates. In contrast to GR and IOM, satellite altimeters directly measure ice-sheet surface elevations.
Radar altimetry technology was realized in ERS (European Remote Sensing) missions ERS-1 and ERS-2, which completed operations in 2000 and 2011, respectively (Davis, 1992). Another radar altimeter aboard the Envisat (Environmental Satellite) mission operated from 2002 to 2010 (Rémy et al., 2009; Memin et al., 2014). The ICESat (The Ice, Cloud and Land Elevation Satellite) and CryoSat-2 (Earth Explorer Opportunity Mission-2) missions have been supplying laser and radar altimetric data on the vertical changes in the surface of Antarctica from 2003 to the present (Drinkwater et al., 2004; Schutz et al., 2005; Wingham et al., 2006; McMillan et al., 2014), with a short gap from 2009 to 2010 that can be partially filled with data from NASA's Operation IceBridge (Koenig et al., 2010). The ICESat mission acquired valuable data on elevation changes in the Greenland and Antarctic ice sheets between 2003 and 2009 using its geoscience laser altimeter system (GLAS) (Zwally et al., 2002). The GLAS included a 1064-nm laser channel for surface altimetry and achieved an overall accuracy of $14 \mathrm{~cm}(5 \mathrm{~cm}$ in flat areas) in its surface elevation measurements (Schutz et al., 2005; Shuman et al., 2006; Moholdt et al., 2010).

The ICESat and CryoSat-2 missions were expected to provide advanced time series data on changes in the Antarctic Ice Sheet. A comparison of the long-term mass changes in the Antarctica Ice Sheet derived from the two independent ICESat and CryoSat-2 data sets over a 6-year period from 2003 to 2009 indicated a strong correlation between the two (Gunter et al., 2009). A similar study on the estimation of Antarctic elevation

\footnotetext{
Corresponding author
} 
and mass change rates was introduced by Memin et al. (2014) using Envisat radar altimetry data for 2003 to 2010. A reconciled estimate of the ice-sheet mass balance using a variety of remote sensing and in situ observations, including GRACE and ICESat data, was reported by Shepherd et al (2012). The first comprehensive assessment of Antarctic ice sheet elevation change using 3 years of CryoSat-2 radar altimeter data was developed by McMillan et al (2014). Zwally et al. (2015) presented that mass gains of the Antarctic ice sheet exceed losses.

This study focuses on the Antarctic ice sheet mass balance derived from ICESat data between 2003 and 2009. Ice sheet elevation and mass change in the Lambert Glacier-Amery Ice Shelf System (LAS), East Antarctica, is calculated using CryoSat-2 data from 2010 to 2015. As illustrated in Figure. 1, the LAS study area is located in the region of $66.5-81^{\circ} \mathrm{S}$ and 40 $95^{\circ} \mathrm{E}$, covering an area of $2,427,820 \mathrm{~km} 2$, including 69,000 $\mathrm{km} 2$ of the Amery ice shelf (Fricker et al., 2000). The LAS is the largest glacier-ice shelf system in East Antarctica.

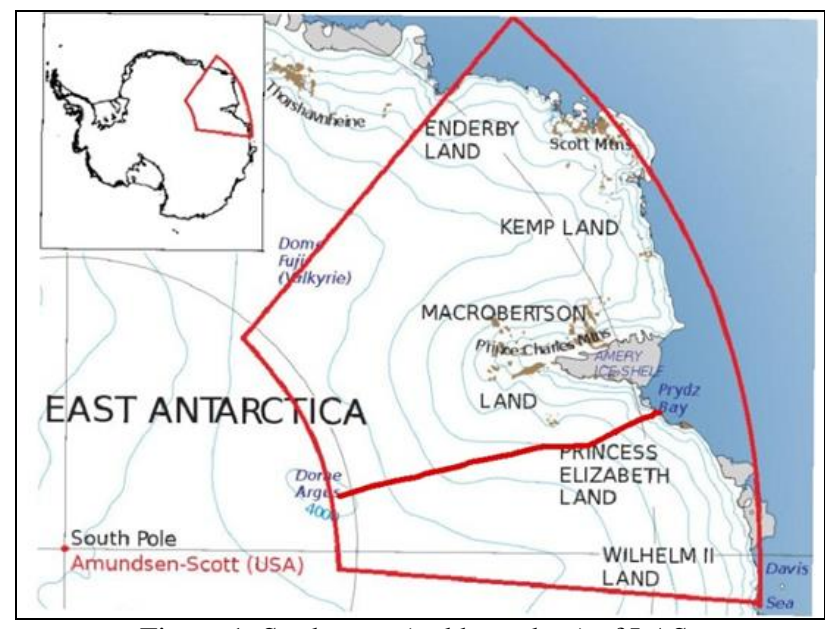

Figure 1. Study area (red boundary) of LAS.

\section{DATA AND METHODS}

\subsection{ICESat Data and Processing}

We used the newly released ICESat GLA12 dataset (R634) Antarctic and Greenland ice sheet altimetry data (ftp://n5eil01u.ecs.nsidc.org/SAN/GLAS/GLA12.034/). This dataset had been recently updated due to the error (called the Gaussian-centroid or "G-C" offset) in the range determination from the transmit-pulse reference-point selection. These intercampaign biases between the different campaigns have been reported to have a maximum impact on the elevation change of $\pm 10 \mathrm{~cm}$ per year (Borsa et al., 2014).

The ICESat data cover the entire mission period from January of 2003 to October of 2009 with a compromised campaign strategy (Table 1) because of the failure of a part of sensor system (Shutz et al., 2005). The first campaign (Campaign 1) works in a different mode whose ground tracks are not repeated as the other campaigns so that we can't apply repeat track analysis to these tracks. Data in campaign 1 is excluded. The last campaign (Campaign 18) was not completed in accordance with its data acquisition plan. Furthermore, Campaign 17 yielded a significant number of empty data areas, based on our data quality examination. Thus, the data from these three campaigns were excluded from this study.
After ICESat data pre-processing above, repeat-track analysis is implemented. First, repeated tracks are separated by track index within GLA12 dataset. Then we fit the repeat track points to a second order polynomial for the tracks. Second, within each $500 \times 500 \mathrm{~m}$ box, we fit four parameters including elevation change rate, mean elevation in the box and slope in $\mathrm{x}$ and $\mathrm{y}$ directions.

Third, we calculate the trend at each cell of a $30 \mathrm{~km} \times 30 \mathrm{~km}$ grid by aggregating estimates of all boxes within the cell and ensure at least five boxes are inside each cell (Ewert et al., 2011).

Similarly, the cells are used to estimate basin and ice sheet level surface elevation change trends. Mass balance calculating is performed at the cell level by multiplying the ice density by the volume change and then extended to the basin and the ice sheet level. GIA correction is applied for ICESat estimates.

$$
h_{i}=\alpha_{x}\left(x_{i}-\bar{x}\right)+\alpha_{y}\left(y_{i}-\bar{y}\right)+\frac{d h}{d t}\left(t_{i}-\bar{t}\right)+\bar{h}
$$

Where

$$
\begin{aligned}
& \mathrm{h}_{\mathrm{i}}=\text { elevation measurement } \\
& \overline{\mathrm{h}}=\text { mean elevation measurement } \\
& \mathrm{x}_{\mathrm{i}}, \mathrm{y}_{\mathrm{i}}=\text { projection coordinates } \\
& \overline{\mathrm{x}}, \overline{\mathrm{y}}=\text { mean projection coordinates in a box } \\
& \mathrm{t}_{\mathrm{i}}=\text { time in year } \\
& \overline{\mathrm{t}}=\text { mean time in year } \\
& \alpha_{\mathrm{x}}, \alpha_{\mathrm{y}}=\text { surface terrain term } \\
& \frac{\mathrm{dh}}{\mathrm{dt}}=\text { elevation change rate }
\end{aligned}
$$

\begin{tabular}{|c|c|c|c|}
\hline $\begin{array}{c}\text { Campaign } \\
\text { No. }\end{array}$ & Date & $\begin{array}{c}\text { Laser } \\
\text { ID }\end{array}$ & Cycle \\
\hline \multirow{2}{*}{1} & $2003-02-20 \sim 2003-03-21$ & $1 \mathrm{~A}$ & 8-day \\
\hline & 2003-03-21 2003-03-29 & 1B & 8-day \\
\hline \multirow{2}{*}{2} & 2003-09-25 2003-10-04 & $2 \mathrm{~A}$ & 8-day \\
\hline & 2003-10-04 2003-11-19 & $2 \mathrm{~A}$ & 91-day \\
\hline 3 & 2004-02-17 2004-03-21 & $2 \mathrm{~B}$ & 91-day \\
\hline 4 & 2004-05-18 2004-06-21 & $2 \mathrm{C}$ & 91-day \\
\hline 5 & 2004-10-03 2004-11-08 & $3 \mathrm{~A}$ & 91-day \\
\hline 6 & $2005-02-17 \sim 2005-03-24$ & $3 \mathrm{~B}$ & 91-day \\
\hline 7 & $2005-05-20 \sim 2005-06-23$ & $3 \mathrm{C}$ & 91-day \\
\hline 8 & 2005-10-21 2005-11-24 & $3 \mathrm{D}$ & 91-day \\
\hline 9 & 2006-02-22 2006-03-28 & $3 \mathrm{E}$ & 91-day \\
\hline 10 & 2006-05-24 2006-06-26 & $3 \mathrm{~F}$ & 91-day \\
\hline 11 & 2006-10-25 2006-11-27 & $3 \mathrm{G}$ & 91-day \\
\hline 12 & 2007-03-12 2007-04-14 & $3 \mathrm{H}$ & 91-day \\
\hline 13 & 2007-10-02 2007-11-05 & $3 \mathrm{I}$ & 91-day \\
\hline 14 & $2008-02-17 \sim 2008-03-21$ & $3 \mathrm{~J}$ & 91-day \\
\hline 15 & 2008-10-04 2008-10-19 & $3 \mathrm{~K}$ & 91-day \\
\hline 16 & $2008-11-25 \sim 2008-12-17$ & $2 \mathrm{D}$ & 91-day \\
\hline 17 & 2009-03-09 2009-04-11 & $2 \mathrm{E}$ & 91-day \\
\hline 18 & 2009-09-30 2009-10-11 & $2 \mathrm{~F}$ & 91-day \\
\hline
\end{tabular}

Table 1. ICESat campaigns and data used in this study 


\subsection{CryoSat-2 Data and Processing}

For CryoSat-2, level 2 data for both LRM (Low Resolution Mode) and SIN (Synthetic Interferometric Mode) in baseline B is used. LRM is a conventional pulse-limited radar altimeter that integrates the backscattered energy over the full beam width resulting in a footprint diameter of roughly $15 \mathrm{~km}$ considering an average altitude of $730 \mathrm{~km}$. In the SIN mode, SIRAL samples the surface with a higher pulse repetition frequency (18 $181 \mathrm{~Hz})$ than in LRM $(1970 \mathrm{~Hz})$ (Helm and others, 2014). Though up to now CryoSat-2 newly baseline $\mathrm{C}$ data is newly released with announced improvement, especially for SIN data, we do not have enough time to make full downloading and validation based processing.

Altogether from July of 2010 to February of 2015, Cryosat-2 has acquired 3.6 million range measurements across Antarctic LAS, East Antarctica, in pulse-limited and synthetic aperture radar interferometry modes, and we process measurements from each mode in an identical manner. Ice sheet elevation is calculated as the difference between satellite locations and range measurements corrected for the lag of the leading edge tracker (Wingham et al., 2006), fluctuations in dry and wet atmospheric mass, the effects of the ionosphere, isostatic rebound (Ivins et al., 2013; Whitehouse et al., 2012), and for solid Earth and ocean tides.

For quality control, Data quality flags are used according to ESA CryoSat-2 user handbook and (Wang et al., 2015). And data of LRM and SARIn are merged together. After CryoSat-2 data pre-processing, followed the grid segment analysis. First, we mesh the study area into 97497 regularly spaced 5 by $5 \mathrm{~km}$ grid. An average of 341 points falls into the 5 by $5 \mathrm{~km}$ box. The average of time range in each box is 4.28 year. Second, within each 5 by $5 \mathrm{~km}$ box, we fit a model with linear elevation change rate, quadratic function of surface terrain and time-invariant function of satellite heading (McMillan et al, 2014). Outliers are removed by iterative three standard deviation filter calculation.

$$
\begin{aligned}
h_{i}= & \alpha_{x}\left(x_{i}-\bar{x}\right)+\alpha_{y}\left(y_{i}-\bar{y}\right)+\alpha_{x x}\left(x_{i}-\bar{x}\right)^{2} \\
& +\alpha_{x y}\left(x_{i}-\bar{x}\right)\left(y_{i}-\bar{y}\right)+\alpha_{y y}\left(y_{i}-\bar{y}\right)^{2} \\
& +\frac{d h}{d t}\left(t_{i}-\bar{t}\right)+\beta_{g} A D_{i}+\bar{h}
\end{aligned}
$$

Where

$$
\begin{aligned}
& \mathrm{h}_{\mathrm{i}}=\text { elevation measurement } \\
& \overline{\mathrm{h}}=\text { mean elevation measurement } \\
& \mathrm{x}_{\mathrm{i}}, \mathrm{y}_{\mathrm{i}}=\text { projection coordinates } \\
& \overline{\mathrm{x}}, \overline{\mathrm{y}}=\text { mean projection coordinates in a box } \\
& \mathrm{t}_{\mathrm{i}}=\text { time in year } \\
& \overline{\mathrm{t}}=\text { mean time in year } \\
& \mathrm{AD}_{\mathrm{i}}=\text { ascending or descending orbit } \\
& \alpha_{\mathrm{x}}, \alpha_{\mathrm{y}}, \alpha_{\mathrm{xx}}, \alpha_{\mathrm{yy}}, \alpha_{\mathrm{xy}}=\text { surface terrain term } \\
& \mathrm{dh}=\text { elevation change rate } \\
& \mathrm{d}_{\mathrm{g}}=\text { offset between ascending and descending }
\end{aligned}
$$

Third, we calculate the trend at each cell of a $30 \mathrm{~km} \times 30 \mathrm{~km}$ grid by aggregating estimates of all boxes within the cell and ensure at least five boxes are inside each cell.

The mass change is computed at the cell level in the same way as the ICESat data. Similarly, GIA correction is implemented for CryoSat-2 estimates.

\section{RESULTS AND DISCUSSION}

\subsection{Calculation Results}

Elevation change rates are resampled to a 30 by $30 \mathrm{~km}$ grid by calculating mean elevation change rate and median absolute deviation (MAD) of errors. Then we calculate mean elevation changes of each basin with errors by error propagation (Ewert et al., 2011). Maps for the elevation change rate of Antarctic ice sheet derived from ICESat data for the period of 2003-2009 is presented in Figure 2. The final surface elevation change rate and the resulting mass change estimation for the whole Antarctica is $0.39 \pm 0.09 \mathrm{~cm} \mathrm{yr}^{-1}$ and $41.03 \pm 9.43 \mathrm{Gt} \mathrm{yr}^{-1}$. Maps for the elevation change rate of LAS, East Antarctica computed from CryoSat-2 data between 2010 and 2015 is displayed in Figure 3.

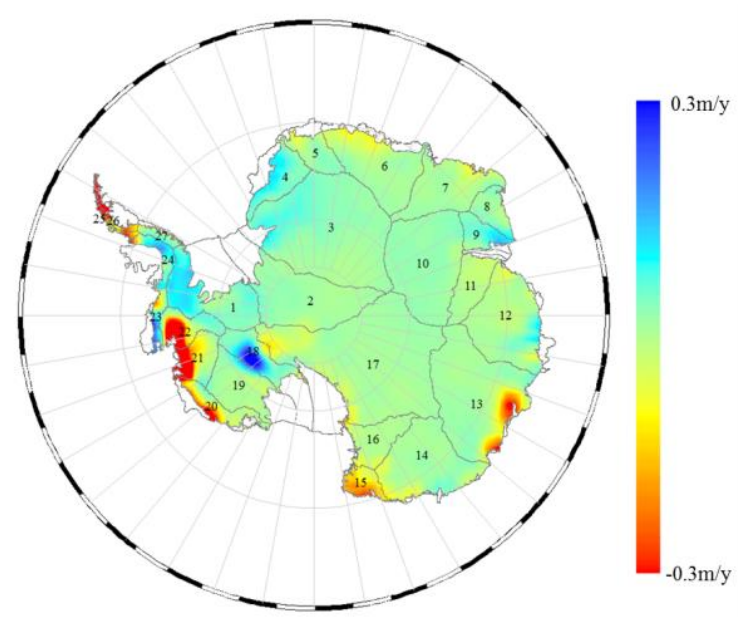

Figure 2. Spatial distribution of elevation change rate of Antarctic ice sheet derived from ICESat data.

\subsection{Further Discussion}

The final result derived from ICESat data reveals that mass gains of the Antarctic ice sheet exceed losses and the detailed mechanism remains to be interpreted.

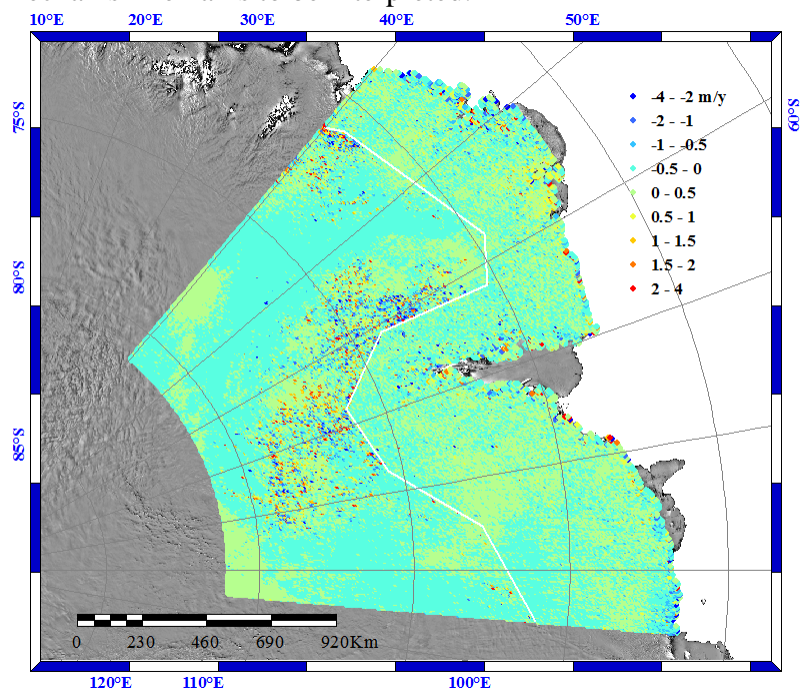

Figure 3. Spatial distribution of elevation change rate of $5 \times 5$ $\mathrm{km}$ boxes in LAS derived from CryoSat-2 data.

The CryoSat-2 data result map (Figure 3) shows a good spatial and temporal quality in the estimation boxes. There is a zone of 
low quality estimates distributed at the margin of LRM mode near upper stream of Amery ice shelf. Further analysis is needed to see if some improvement may be necessary in Level 1 data reprocessing or in our model. We are calculating the mass balance of the whole study area, and a further investigation of the trend from 2010 to 2015 needs to be carried out in terms of detailed data quality, estimation model, snow accumulation data, and others.

\section{CONCLUSION}

A comprehensive assessment of Antarctic ice sheet surface mass balance is implemented here using ICESat data from 2003-2009 and detailed elevation change estimation and mass balance of LAS, East Antarctica is also presented using CryoSat-2 data from 2010-2015. The Antarctic ice sheet mass gains go beyond losses supported by calculated result from ICESat data. And a zone of low quality estimates in LAS needs more investigation.

\section{ACKNOWLEDGEMENTS}

This work has been supported by National Key Basic Research Program of China (No. 2012CB957701).

\section{REFERENCES}

Bamber, J., Riva REM, Vermeersen BLA and LeBroq AM, 2009. Reassessment of the potential sea-level rise from a collapse of the West Antarctic Ice Sheet. Science, 324 (5929), pp. 901-903.

Borsa, AA., G. Moholdt, H. A. Fricker, and K. M. Brunt, 2014. A range correction for ICESat and its potential impact on ice sheet mass balance studies, The Cryosphere, vol. 8, pp. 345-357.

Cazenave, A., and Llovel W., 2010. Contemporary sea level rise. Annu. Rev. Mar. Sci., 2, pp. 145-173.

Chen, JL., Wilson C. R., Blankenship D. and Tapley BD., 2009. Accelerated Antarctic ice loss from satellite gravity measurements. Nat. Geosci., 2(12), pp. 859-862.

Davis, CH., 1992. Satellite radar altimetry. IEEE T. Microw. Theory, 40(6), pp. 1070-1076.

Domingues, CM., Church JA, White NJ, Gleckler PJ, Wijffels SE, Barker PM and. Dunn JR, 2008. Improved estimates of upper-ocean warming and multi-decadal sea-level rise. Nature, 453, pp. 1090-1093.

Drinkwater, MR., Francis R, Ratier G and Wingham D, 2004 The European Space Agency's Earth Explorer mission CryoSat: Measuring variability in the cryosphere. Ann. Glaciol., 39(1), pp. 313-320.

Ewert, H., Groh A, Dietrich R., 2012. Volume and mass changes of the Greenland ice sheet inferred from ICESat and GRACE, Journal of Geodynamics, 59, pp. 111-123.

Fricker, HA., Warner RC and Allison I., 2000. Mass balance of the Lambert Glacier-Amery Ice Shelf system, East Antarctica: A comparison of computed balance fluxes and measured fluxes. $J$. Glaciol., 46(155), pp. 561-570.

Flament, N., Gurnis M and Muller R., 2013. A review of observations and models of dynamic topography. Lithosphere, 5(2), pp. 189-210.
Gunter, B., Urban T, Riva R, Helsen M, Harpold R, Poole S, Nagel P, Schutz B and Tapley B., 2009. A comparison of coincident GRACE and ICESat data over Antarctica. J. Geod., 83(11), pp. 1051-1060.

Helm, V., A. Humbert, and H. Miller, 2014. Elevation and elevation change of Greenland and Antarctica derived from CryoSat-2. The Cryosphere, 8, pp. 1539-1559.

Ivins, ER., 2009. Ice sheet stability and sea level. Science, 324(5929), pp. 888-889.

Ivins, ER., T. S. James, J. Wahr, E. J. Schrama, F. W. Landerer, and K. M. Simon (2013), Antarctic contribution to sea level rise observed by GRACE with improved GIA correction, $J$. Geophys. Res. Solid Earth, 118, pp. 3126-3141.

Koenig, L., Martin S, Studinger M and Sonntag J., 2010. Polar airborne observations fill gap in satellite data. Eos Trans. AGU, 91(38), pp. 333.

Liu, Y., Moore JC, Cheng X, Gladstone RM, Bassis JN, Liu H, Wen $\mathbf{J}$ and Hui F., 2015. Ocean-driven thinning enhances iceberg calving and retreat of Antarctic ice shelves. Proc. Natl. Acad. Sci. USA, 112(11), pp. 3263-3268.

Moholdt, G., Padman L and Fricker HA, 2014. Basal mass budget of Ross and Filchner-Ronne ice shelves, Antarctica, derived from Lagrangian analysis of ICESat altimetry. $J$. Geophys. Res., 119, pp. 2361-2380.

Memin, A., Flament T, Rémy F and Llubes M., 2014. Snowand ice-height change in Antarctica from satellite gravimetry and altimetry data. Earth Planet. Sci. Lett., 404, pp. 344-353.

McMillan, M., Shepherd A, Sundal A, Briggs K, Muir A, Ridout A, Hogg A and Wingham D, 2014 Increased ice losses from Antarctica detected by CryoSat-2. Geophys. Res. Lett., 41, pp. 3899-3905.

Paolo, FS., Fricker HA and Padman L., 2015. Volume loss from Antarctic ice shelves is accelerating. Science, 348(6232), pp. 327-331.

Rignot, E., Velicogna I, van den Broeke MR, Monaghan A and Lenaerts J., 2011. Acceleration of the contribution of the Greenland and Antarctic ice sheets to sea level rise. Geophys. Res. Lett., 38, pp. L05503.

Rémy, F., and Parouty S., 2009. Antarctic Ice Sheet and Radar Altimetry: A Review. Remote Sensing, 1(4), pp. 1212-1239.

Shepherd, A., Ivins ER, Geruo A, Barletta VR, Bentley MJ, Bettadpur S, Briggs KH, Bromwich DH, Forsberg R, Galin N, Horwath M, Jacobs SJ, Joughin I, King M A, Lenaerts JTM, Li J, Ligtenberg SRM, Luckman A, Luthcke SB, McMillan M, Meister R, Milne G, Mouginot J, Muir A, Nicolas JP, Paden J, Payne AJ, Pritchard H, Rignot E, Rott H, Sørensen LS, Scambos TA, Scheuchl B, Schrama EJO, Smith B, Sundal AV, van Angelen JH, van de Berg WJ, van den Broeke MR, Vaughan DG, Velicogna I, Wahr J, Whitehouse PL, Wingham DJ, Yi D, Young D and Zwally HJ, 2012, A Reconciled Estimate of Ice-Sheet Mass Balance. Science, 338(6111), pp. 1183-1189. 
Schutz, BE., Zwally HJ, Shuman CA, Hancock D and DiMarzio JP (2005) Overview of the ICESat mission. Geophys. Res. Lett., 32, pp. L21S01.

Shuman, CA., Zwally HJ, Schutz BE, Brenner AC, DiMarzio JP, Suchdeo VP and Fricker HA., 2006. ICESat Antarctic elevation data: Preliminary precision and accuracy assessment. Geophys. Res. Lett., 33, pp. L07501.

Vaughan, DG., Comiso JC, Allison I, Carrasco J, Kaser G, Kwok R, Mote P, Murray T, Paul F, Ren J, Rignot E, Solomina O, Steffen K and Zhang T, 2013. Observations: Cryosphere, in Climate Change 2013, The Physical Science Basis. Contribution of Working Group I to the Fifth Assessment Report of the Intergovernmental Panel on Climate Change, edited by Stocker and others, pp. 317-383, Cambridge University Press, Cambridge, United Kingdom and New York, NY, USA.

Wingham, DJ., Francis CR, Baker S, Bouzinac C, Brockley D, Cullen R, de Chateau-Thierry P, Laxon SW, Mallow U, Mavrocordatos C, Phalippou L, Ratier G, Rey L, Rostan F, Viau P and Wallis DW., 2006. CryoSat: A mission to determine the fluctuations in Earth's land and marine ice fields. $A d v$. Space Res., 37(4), pp. 841-871.

Whitehouse, PL., M. J. Bentley, G. A. Milne, M. A. King, and I. D. Thomas (2012), A new glacial isostatic adjustment model for Antarctica: Calibrated and tested using observations of relative sea-level change and present-day uplift rates, Geophys. J. Int., 190(3), pp. 1464-1482.

Wang, F., Bamber J L and Cheng X., 2015. Accuracy and Performance of CryoSat-2 SARIn Mode Data Over Antarctica. IEEE Geocience and Remote Sensing Letter, 12(7), pp. 15161520.

Zwally, HJ., and Li J, 2002. Seasonal and interannual variations of firn densification and ice-sheet surface elevation at Greenland summit. J. Glaciol., 48(161), pp. 199-207.

Zwally, HJ., and M. B. Giovinetto, 2011a. Overview and assessment of Antarctic ice-sheet mass balance estimates: 19922009, Surv. Geophys., 32, pp. 351-376.

Zwally. HJ., Li Jun, John W. ROBBINS, Jack L. SABA, Donghui YI, Anita C. BRENNER, 2015. Mass gains of the Antarctic ice sheet exceed losses. Journal of Glaciology, 61(230), pp. 1019-1036. 